Swietłana Wiśniewska

\title{
Postać Samarytanki (J 4, 1-42) w tradycji Kościoła wschodniego
}

Jak wszystkie inne pisma NT Ewangelia Janowa powstawała w określonym środowisku kościelnym i dla potrzeb tego środowiska. Jeszcze w pierwszym okresie postania tzw. wspólnoty Janowej ważną rolę w niej odgrywali członkowie pochodzenia samarytańskiego ${ }^{1}$. B. Lindars ${ }^{2}$ uważa, że autor czwartej Ewangelii miał nadzwyczajną zażyłość z Samarytanami. Świadczy o tym znajomość topografii, ich zwyczajów i wierzeń.

J 4, 1-42 jest swego rodzaju „historią początków” obecności Samarytan w chrześcijaństwie i we wspólnocie. Początki te są bardzo wzniosłe: nawraca ich sam Chrystus, który pierwszy przychodzi do wioski samarytańskiej, osobiście spotyka jej mieszkańców i głosi im Dobrą Nowinę. Ale zawsze istniał (i nadal istnieje) problem egzegetyczny: czy wydarzenia opisywane w J 4, 1-42 są wydarzeniami historycznymi, czy naprawdę odbyło się spotkanie Jezusa i Samarytanki, które zapoczątkowało obecność Samarytan w Kościele Chrystusowym, czy dialog pomiędzy nimi odbywał się w takich samych słowach, które przytacza Ewangelia Janowa? Odpowiedzi na te pytania są dosyć zróżnicowane.

Egzegeza traktuje wydarzenia opisane w J 4, 1-42 w czterech modelach: historyczno-biograficznym, symboliczno-alegorycznym, historii zbawienia i sakramentalnym ${ }^{3}$.

Model historyczno-biograficzny traktował J 4, 1-42 jako opis realnego faktu historycznego z życia Jezusa, jako jeden z epizodów jego biografii. Taka interpretacja J 4, 1-42 jest charakterystyczną dla komentarzy sprzed wieku XIX. Chociaż komentatorzy zauważają rozwój wiary Samarytanki w trakcie jej rozmowy z Jezusem, postacią centralna perykopy jest Jezus.

${ }^{1}$ Według R. Browna i M.-É. Boismarda Samarytanie weszli do wspólnoty Janowej w tzw. I fazie (ok. 55 - ok. 85). Zob. S. MęDALA, Tradycja Janowa w świetle wspótczesnych badań, [w:] Mów, Panie, bo stucha stuga Twój. Księga pamiątkowa dla księdza profesora Ryszarda Rubinkiewicza, Warszawa 1999, s. 154.

${ }^{2}$ B. Lindars, The Gospel of John (New Century Bible), London 1972, s. 175n.

${ }^{3}$ B. Olsson, Structure and meaning of the Fourth Gospel, Lund 1974, s. 119. 
Uważano, że opis wszystkich dialogów i wydarzeń jest czymś w rodzaju stenogramu rozmów Jezusa z Samarytanka, a potem z uczniami i z Samarytanami. To samo dotyczy opisu wszystkich wydarzeń z J 4, 1-424.

Obok takiego rozumienia tej perykopy istniał symboliczno-alegoryczny model interpretacyjny. W przeciwstawieniu do modelu historyczno-biograficznego ukazywał J 4, 1-42 w kategoriach metaforycznych. Za takim modelem wypowiadają się już Orygenes i Herakleon. Ten ostatni rozumiał dialog Jezusa i Samarytanki jako symboliczny opis spotkania duszy z Bogiem. Taką drogą poszło wielu egzegetów, szczególnie w wiekach XIX-XX. Przykładowo, B. Odenberg traktował J 4, 1-42 jako spotkanie ortodoksyjnej teologii samarytańskiej z modelem chrześcijaństwa reprezentowanym przez wspólnotę Janową. S. Leroy uważał, że J 4, 1-42 stanowi epizod z historii Kościoła Janowego, który notuje fakt wejścia Samarytan-chrześcijan do składu wspólnoty Janowej5.

O. Cullman także wypowiada się za taką interpretacją, ale dodaje aspekt historii zbawienia $\mathrm{i}$ aspekt sakramentalny, odnajdując $\mathrm{w}$ tej perykopie odniesienia do chrztu i Eucharystii. Takie podejście charakteryzuje się łączeniem interpretacji historycznej i interpretacji symbolicznej ${ }^{6}$.

Odmianą interpretacji soteriologicznej jest interpretacja chrystologiczna, w centrum której znajduje się osoba Jezusa Chrystusa. R. Bultmann uważa, że J 4, 1-42 jest demonstracją tego, w jaki sposób Bóg objawia się tym, którzy go szukają. Centralnym w tym objawieniu jest moment decyzji człowieka, to, po czyjej stronie on się wypowiada: po stronie Boga czy świata. Za takim rozumieniem są także R. Schnackenburg, R. Brown i B. Lindars?.

Przez długi okres czasu spotkanie Jezusa z Samarytanka w tradycji Kościoła Katolickiego było uważane za fakt historyczny. Ale ostatnie badania ukazały raczej, że nie można z pewnością ustalić, czy to spotkanie jest faktem historycznym, czy też tworem wyobraźni ewangelisty. Według R. Bultmanna pierwotne znaczenie tego epizodu miało sens podobny jak w tradycji buddyjskiej, gdzie Ananda, uczeń Buddy, prosi służącą z niskiej kasty o wodę ${ }^{8}$. Oprócz tego, tradycja Kościoła Zachodniego nie zna imienia Samarytanki ${ }^{9}$.

Tradycja synoptyczna świadczy, że Jezus nie prowadził żadnej działalności w Samarii (Mt 10, 5n; Łk 9, 51-56). Dlatego uważa się, że w J 4, 1-42 została opisana misja Kościoła z pierwszych lat jego działalności. Z Dz 8 dowiadujemy

\footnotetext{
${ }^{4}$ Tamże, s. $119-120$.

5 Tamże, s. 121.

${ }^{6}$ Tamże.

${ }^{7}$ Tamże, s. 122-123.

${ }^{8}$ Tamże, s. 118.

${ }^{9}$ C. Koester, The Savior of the Word (John 4: 42), JBL 109 (1990), s. 671.
} 
się o tym, jak przebiegała tzw. misja samarytańska. Narzuca się rozumienie, że było to raczej pierwsze spotkanie Samarytan z Chrystusem, a nie spotkanie Jezusa i Samarytanki. Był to Chrystus żyjący w swoim Kościele.

Lecz wyniki badań genezy tekstu przeprowadzone przez H. Ritt zaświadczyły, że w dialogu Jezusa z Samarytanką znajdują się autentyczne wspomnienia z życia Jezusa. Elementy poetyckie i retoryczne tego tekstu wskazują na historyczność dialogu. Według A. Reformackiego forma użycia czasowników (imperfektum i perfektum) także może świadczyć o historyczności narracji ${ }^{10}$. Za historycznością opisywanego wydarzenia przemawia także gatunek literacki Ewangelii, który jest najbliższy starożytnym biografiom hellenistycznym ${ }^{11}$. To pozwala wnioskować, że takie spotkanie miało miejsce lub mogło mieć miejsce ${ }^{12}$.

W tradycji Kościoła Wschodniego nie ma żadnych wątpliwości co do historyczności dialogu Jezusa z Samarytanką. Samarytanka niewątpliwie jest postacią historyczną. Ma na imię Fotyna od greckiego photos - światło ${ }^{13}$. Wspomnienie św. Fotyny Kościół prawosławny obchodzi 2 kwietnia (20 marca). Troparion święta brzmi: „Służebnica twoja, Jezusie, Fotyna, woła donośnym głosem: Ciebie, Oblubieńcze mój, kocham, Ciebie szukając razem z Tobą cierpię i idę na krzyż, umieram razem z Tobą i króluję, życie odnajduję w Tobie. Przyjmij mnie jako doskonałą ofiarę miłości. Twoja modlitwa niech uratuję moją duszę". Kondakos święta jest następujący: „W święto twoje odnajdując pokój naszych dusz jednym głosem wołamy: „Święta męczennico Fotyno, módl się do Boga za nami”.

Tradycja wschodnia informuje, że Fotyna miała dwóch synów: Wiktora, zwanego Fotynem i Ozeasza. Razem z ostatnim mieszkała i głosiła Ewangelię w Kartaginie. Starszy jej syn był dowódcą w armii rzymskiej. Razem z nimi została umęczona w ok. 66 r. podczas prześladowań za cesarza Nerona. Jej kościół i szczątki znajdowały się w Konstantynopolu ${ }^{14}$. Czetji-Minieji - księga czytań liturgicznych żywotów świętych - przedstawia dokładny opis jej męczeństwa ${ }^{15}$.

Opis zaczyna się od historii nawrócenia burmistrza jednego z miast Atalii, Sebastiana. Nawrócił go syn Samarytanki Wiktor, który po kolejnej wojnie

${ }^{10}$ А. Реформатский, Опыт анализа новвелистической композичии, [w:] Семиотика, ред. Ю. Степанов, Москва 1983, s. 558.

${ }^{11}$ M. WoJcIEchowski, Ewangelie jako biografie, RBL 94 (1998), s. 175.

${ }^{12}$ M. Wojciechowski, Ewangelie jako biografie, art. cyt., s. 176.

${ }^{13}$ Adaptując do słowiańskich realiów nazywają ją Swietłana Palestyńska.

${ }^{14}$ Полный православный богословский словарь, ред. А. Лопухин, П. Глубоковский, t. 2, Москиа 1992, s. 78.

${ }^{15}$ ДимитРй̆, Епископ Ростовский, Жития святьх. Книга седьмая: март, Оптина пустынь 1993, s. 407-413. 
Rzymu z barbarzyńcami był mianowany dowódcą wojsk w tym mieście. Jako dowódca otrzymuje nakaz od imperatora Nerona, aby prześladować chrześcijan. Sebastian wie, że Wiktor jest chrześcijaninem, ale namawia go do podporządkowania się władzy cesarza, ponieważ Wiktor otwarcie wyznaje swoja wiarę i odmawia posłuszeństwa cesarzowi. Sebastian tłumaczy mu, że można w razie uległości Wiktora uratować jego matkę i brata, zamieszkujących w Kartaginie, od prześladowań za wiarę. Proponuje Wiktorowi i jego rodzinie zaprzestać jawnego wyznawania Chrystusa i nawracania pogan, żeby nie różnić się zachowaniem od otoczenia pogańskiego.

Wiktor jednak nie odstępuje od swego postanowienia i woli raczej umrzeć, niż wypełnić rozkaz imperatora. Wtedy Sebastian zaczyna otwarcie grozić jemu i jego rodzinie. Ale Bóg karze Sebastiana. Podobnie jak św. Paweł jest on rzucony na ziemię. Przez trzy dni i trzy noce nie widzi i nie mówi. Po upływie tego okresu „donośnym głosem” wyznaje Chrystusa jako Boga jedynego i prawdziwego. Wiktor przygotowuje go do chrztu i udziela tego sakramentu. Razem z Sebastianem nawraca się liczna służba jego domu.

Ten przykład pociąga coraz więcej Atalijczyków do Chrystusa. Wieść o szerzeniu się chrześcijaństwa dociera do Nerona. Imperator wzywa wyznawców Chrystusa z Atalii do Rzymu w celu dokonania nad nimi sądu. To oznacza męczeństwo. Atalijczycy na czele z Wiktorem wyruszają do Rzymu. W drodze ukazuje się im Chrystus obiecując swoją stała obecność podczas przyszłych cierpień za wiarę. Wiktor otrzymuje nowe imię od Boga-Fotyn, „ponieważ wielu oświeconych przez ciebie nawróci się do Mnie”.

Analogicznie do wyżej opisanego wydarzenia można wnioskować, że imię Samarytanki - Fotyna - też mogło nie być imieniem nadanym jej przy urodzeniu. Tak samo, jak w wypadku jej syna, mogło to być imię otrzymane od Chrystusa.

Chrześcijanie z Kartaginy razem ze św. Fotyną i jej synem Ozeaszem także są w drodze do Rzymu w odpowiedzi na wezwanie cesarza. Św. Fotyna już wie od Boga o nadchodzących cierpieniach. Kiedy ona wchodzi do miasta, cały Rzym zostaje poruszony jej widokiem: wszyscy pytają, kim jest ta kobieta. Tu oprócz synów Samarytanki wzmiankowane jest także jej pięć sióstr, które też są chrześcijankami z Kartaginy: Anastazja, Foto, Fotyda, Paraskiewa i Kirijakija. Dowiadujemy się, ze św. Fotyna jest najstarsza z nich. Znów mamy do czynienia z imionami raczej chrześcijańskimi niż żydowskimi albo hellenistycznymi.

Chrześcijanie mężnie odrzucają propozycje Nerona, aby zaprzeć się swojej wiary, i zostają skazani na okropne tortury. Lecz staje się cud: torturowanie trwa kilka godzin, ale nie odnoszą skutku, oprócz tego męczennicy nie czują bólu. Wtedy Sebastian, Fotyn, Ozeasz i św. Fotyna 
razem z siostrami zostają wtrąceni do więzienia. Ale i tam nie zaprzestają głoszenia Chrystusa i nawracają wiele ludzi. To naraża ich na kolejne okrutne tortury, które w tym wypadku kończą się śmiercią męczeńską. Opis zamyka wymowna scena: św. Fotyna pluje w twarz Neronowi i „śmiejąc się nad jego głupotą, rzecze: - «O rozpustny ślepcze, błądzący człowieku bez okruszyny rozumu! Chyba uważasz mnie za taką samą jak ty, jeśli chcesz, żebym wyrzekła się Chrystusa i złożyła ofiarę podobnym do ciebie ślepym bożkom?»" Po czym zostaje utopiona w studni.

W tym epizodzie daje się odczuć polemika z kultem imperatora i odniesienie do rozmowy Samarytanki z Jezusem przy studni Jakubowej. Studnia tu symbolizuje pełnię życia chrześcijańskiego, którą osiągnęła święta po śmierci dzięki swemu męczeństwu.

Oczywiście, nie można uważać tego opisu za dokument historyczny. Jest to przede wszystkim utwór literacki, zbudowany zgodnie z zasadami literatury pięknej tamtego czasu. Tradycja bizantyjska jako tradycja wschodnia jest nacechowana alegoriami i metaforami, które pomagają raczej głębiej zrozumieć sens przesłania, które zawiera opis, niż odtwarzają realny przebieg faktów. Niestety nie wiemy o istnieniu jakichś dokumentalnych świadectw (oprócz tego, co przytacza tradycja Kościoła Wschodniego) na temat życia i męczeństwa Samarytanki. Dlatego kwestia historyczności tej postaci wciąż pozostaje nie rozstrzygniętą.

Ale jeśli przyjąć, że Samarytanka jest postacią historyczną i że to właśnie św. Fotyna rozmawiała z Jezusem przy studni w Sychar, nie była to raczej dokładnie taka rozmowa, jaką nam opisuje czwarta Ewangelia. Taką „zdradę faktu" dopuszcza gatunek literacki biografii hellenistycznej. Ta rozmowa jest jakby „ikoną" interpretację ${ }^{17}$. Samarytanka ma wiele wspólnych cech z Marią Magdaleną: cudzołożna kobieta, która spotyka Jezusa, w Nim jak w prawdziwym Bogu odnajduje swoją pierwotną miłość. Zarówno Samarytanka, jak i Maria Magdalena pomaga Jezusowi w jego misji apostolskiej ${ }^{18}$. Lecz jej historia z czasem traci realne cechy - staje się historią odnalezienia pierwotnej miłości narodu samarytańskiego ${ }^{19}$.

Warszawa

SWIETEANA WIŚNIEWSKA

${ }^{16}$ С. Моррис, Основная теория знаков, s. 56; Р. Якоьсон, В поисках сущности языка, s. 104, [w:] Семиотика, ред. Ю. Степанов, Москва 1983.

${ }^{17}$ R. FABRIs, Giovanni, Roma 1992, s. 300-301; В. Истомин, Слово Божие, Логос 29-32 (1978), s. 137; B. Olsson, Structure and meaning of the Fourth Gospel, dz. cyt., s. 121-122.

${ }^{18} \mathrm{G}$. Behler, Le source en quête de l'assoifée. L'entrétien de Jésus avec la Samaritaine (Jean 4, 1-42), Paris 1980, s. 132. 


\section{Résumé}

La Samaritaine (Jn 4, 1-42) dans la tradition de l'Eglise orientale

Tandis que la tradition de l'Occident ne connaît pas le nom de la Samaritaine, dans la tradition orientale elle porte le nom Fotine (du grec phôs - lumière), c'est-à-dire „Illuminée”. Lentretien de Jésus avec la Samaritaine est quasi une icône: l'événement historique reçoit une interprétation symbolique et théologique. La femme de Samarie est comme Marie Madeleine une collaboratrice de Jésus et de ses apôtres.

${ }^{19}$ Por. W. Barclay, Ewangelia wedtug św. Jana, tłum. K. Bednarczyk, Warszawa 1986, s. 231; E. Bотна, Jesus and Samaritan Woman. A Speech Act Reading of John 4, 1-42, Leiden 1991, s. 186 (SupplNovT 65); G. Burg, John. The NIV Application Commentary, Michigan 2000, s. 161; R. CULPEPPER, The Gospel and Letters of John (Interpreting Biblical Texts), Nashville 1998, s. 140; R. FABRIS, Giovanni, dz. cyt., s. 301; B. Olsson, Structure and meaning of the Fourth Gospel, dz. cyt., s. 142; W. ŚwIERZAWski, Pierwszy umiłował. Komentarz do Ewangelii Jezusa Chrystusa wedtug świętego Jana, Wrocław 1982, s. 126. 